\title{
Anti-inflammatory activity of hydroalcoholic extract of mimosa pudica whole plant in rats
}

\author{
Parvathy Velayudhan Nair*, Bindu Latha R. Nair
}

\begin{abstract}
Government Medical College, Thiruvananthapuram, Kerala 695011, India
\end{abstract}

Received: 17 January 2017

Accepted: 31 January 2017

*Correspondence to:

Dr. Parvathy Velayudhan Nair, Email:

devikahari2002@gmail.com

Copyright: (C) the author(s), publisher and licensee Medip Academy. This is an openaccess article distributed under the terms of the Creative Commons Attribution NonCommercial License, which permits unrestricted noncommercial use, distribution, and reproduction in any medium, provided the original work is properly cited.

\begin{abstract}
Background: Mimosa pudica is a traditionally used folk medicine to treat various disorders like infections, anxiety, depression, bleeding disorders, convulsions, rheumatoid arthritis, muscular pain, asthma, snake bite etc. We evaluated the anti-inflammatory activity of hydroalcoholic extract of Mimosa pudica whole plant (HAEMPWP) in rats.

Methods: HAEMPWP was prepared using Soxhlets apparatus. Acute toxicity tests were done with HAEMPWP given orally to albino rats in increasing doses up to $3200 \mathrm{mg} / \mathrm{kg}$ body weight. The anti-inflammatory action was evaluated by Carrageenan induced paw edema method. Thirty albino rats were grouped into five groups and each contained six rats. Group I (control group) received distilled water orally. Group II (standard) received Aspirin orally dissolved in distilled water. Groups III, IV and V received HAEMPWP in doses of 200 $\mathrm{mg} / \mathrm{kg}, 400 \mathrm{mg} / \mathrm{kg}$ and $800 \mathrm{mg} / \mathrm{kg}$ orally dissolved in distilled water. Data analysis was done by one way ANOVA and unpaired t test using SPSS 16 for windows.
\end{abstract}

Results: HAEMPWP showed a significant anti-inflammatory activity as compared to control. There was no statistically significant dose dependent increase in the anti-inflammatory activity.

Conclusions: HAEMPWP possesses significant anti-inflammatory activity and could be an effective treatment option for various inflammatory conditions.

Keywords: Albino rats, Anti-inflammatory, Carrageenan, Mimosa pudica, Soxhlet apparatus

\section{INTRODUCTION}

Glucocorticoids and Non Steroidal Anti-inflammatory drugs (NSAIDS) comprise the main chunk of antiinflammatory drugs in use. Glucocorticoids are having powerful anti-inflammatory and immunosuppressive effects. They inhibit all phases of inflammation including the early and late phases, whereby it reduces the redness, heat, pain and swelling along with a reduction in tissue repair and wound healing .NSAIDs act by inhibiting Cyclo-oxygenase (COX) enzyme. Most of the NSAIDs act non specifically on both COX variants (COX 1 and COX 2), but the newer NSAIDs act only on COX 2 enzyme. Action of NSAIDs is limited to the early phases of inflammation. ${ }^{1}$

Celsus characterized inflammation by the four Latin words Rubor, Calor, Dolor and Tumor, two thousand years ago. These four words typically depict the features of inflammation - rubor meaning redness, calor meaning heat, dolor meaning pain and tumor meaning swelling. Inflammation is divided into three phases: acute inflammation, the immune response and chronic inflammation. $^{2}$ Acute inflammation is the initial response to tissue injury mediated by the release of autacoids. Immune response occurs when immunologically competent cells are activated in response to foreign organisms or antigenic substances liberated during inflammatory response. Chronic inflammation involves the release of a number of mediators that are not prominent in the acute response and is characterized by granuloma formation.

The cyclo-oxygenase (COX) pathway of arachidonic acid metabolism produces prostaglandins that have a variety of effects on blood vessels, on nerve endings, and on cells 
involved in inflammation. COX 2 is induced in cells by an inflammatory stimulus and is responsible for production of mediators of inflammation. ${ }^{3}$ Three important aspects of inflammation that can be readily measured are erythema (local vasodilatation), edema (increased capillary permeability) and formation of granulation tissue. Compounds claimed to possess antiinflammatory activity can be evaluated by their ability to reduce these phenomena in experimentally induced inflammation. ${ }^{4}$ Carrageenan induced paw edema is a model of acute inflammation used in the study of NSAID. ${ }^{5}$

Mimosa pudica was first described from Brazil and is native to most of the New World Tropics. ${ }^{6}$ Today it is considered to be a pantropical weed and it is common in moist grounds, open plantations and weedy thicklets. The scientific name of this plant, Mimosa pudica is derived from Greek, (Mimos meaning a mimic which alludes to the sensitivity of the leaves) and Latin, (pudica, meaning bashful, retiring or shrinking). ${ }^{8-10}$ The plant grows wildly as a rapidly growing shrub. The fern like leaves close up and droop when touched, and re-opens within minutes. Phytochemical studies had revealed the presence of alkaloids like mimosine, crocetin, tubulin, turgorines, flavanoids, tannin, sitisine. ${ }^{11,12}$

The medicinal use of the plant dates back to Charaka and Sushruta. ${ }^{13,14}$ The plant is traditionally used for disorders like convulsions, anxiety, stress, depression. It is also used to treat menorrhagia, dysentery with blood and mucus, piles and fistula It is effective in relieving the symptoms of rheumatoid arthritis, spasmodic conditions and muscular pain. ${ }^{15}$ The roots of M. pudica are bitter, astringent and cooling and they are used in the treatment of ulcers, inflammations, asthma and diarrhea. The plant also exhibits various medicinal activities like antihistaminic, antidepressant, hyperglycaemic, muscle relaxant, hemostatic, antifertility, antibacterial, anticonvulsant, antisnake venom, antifungal, antimalarial, anticancer activities and is also an immunomodulator. ${ }^{16-18}$ It is used in traditional medicine for the treatment of various inflammatory conditions. So we decided to evaluate the anti-inflammatory activity of HAEMPWP in albino rats.

\section{METHODS}

\section{Plant material and extract}

The whole plant of Mimosa pudica was collected locally and authenticated by the Central Pharmacognosy unit, Ayurveda Research Institute, Poojappura, Thiruvananthapuram. The fresh whole plants of Mimosa pudica were washed thoroughly in water to remove soil material. It was then cut into small pieces, shade dried and powdered. Extract was prepared as per the method of Rosenthaler using Soxhlet apparatus. ${ }^{19}$ The solvent used was $50 \%$ water and $50 \%$ alcohol. About $2.4 \mathrm{~kg}$ of the plant yielded about $32.3 \mathrm{~g}$ of a sticky semisolid mass which was dark green in colour with a pungent odour. The extract was stored in a refrigerator.

\section{Experimental animals}

Wistar strain albino rats (150-200 grams) of either sex were used. The animals were housed under standard laboratory conditions in the animal house of Thiruvananthapuram Medical College. The animals were fed standard pellet diet, maintained on a natural light and dark cycle and had free access to food and water. They were acclimatized to laboratory conditions before the tests. The experimental protocols were approved by the Institutional Animal Ethics Committee (Proposal No. 65/ IAEC/ MCT/07) of Thiruvananthapuram Medical College and ethical guidelines were followed throughout the study.

\section{Drugs and chemicals}

Aspirin tablet and Carrageenan (Sigma Labs, Mumbai), Distilled water, HAEMPWP 200, 400 and $800 \mathrm{mg} / \mathrm{kg}$. An aqueous suspension of the extract was prepared in distilled water and used for the study.

\section{Acute toxicity study and study on gross behavioral changes}

Albino rats of either sex weighing 15-20 grams were used for the study. ${ }^{20}$ They were divided into 5 groups of 2 rats each. The rats were observed for effects on central nervous system and autonomic changes continuously for 2 hours and then occasionally for further 4 hours and finally overnight mortality recorded. As there was no mortality with $50 \mathrm{mg} / \mathrm{kg}, 70 \mathrm{mg} / \mathrm{kg}, 100 \mathrm{mg} / \mathrm{kg}, 125$ $\mathrm{mg} / \mathrm{kg}$, toxicity studies were repeated using $200 \mathrm{mg} / \mathrm{kg}$, $400 \mathrm{mg} / \mathrm{kg}, 800 \mathrm{mg} / \mathrm{kg}, 1600 \mathrm{mg} / \mathrm{kg}, 2400 \mathrm{mg} / \mathrm{kg}$ and $3200 \mathrm{mg} / \mathrm{kg} .{ }^{17}$

\section{Assessment of anti-inflammatory activity}

Effect of the HAEMPWP on acute inflammation was studied by the method described by winter and coworkers, where paw edema was induced using carrageenan and edema measured using modified plethysmometer. $^{21}$

Albino rats of either sex weighing between 150 and 300 grams were used for the study. The rats were weighed and divided into 5 groups containing 6 rats each. A mark was made on the skin over the lateral malleolus to ensure constant paw volume every time the paw was dipped up to the fixed mark. The rats were fasted overnight. The next morning they were given the following drugs orally. The first group (control group) received $5 \mathrm{ml}$ of distilled water. The second group received the standard drug, Aspirin at a dose of $300 \mathrm{mg} / \mathrm{kg}$. The third, fourth and fifth groups received the test drug at doses of $200 \mathrm{mg} / \mathrm{kg}, 400$ $\mathrm{mg} / \mathrm{kg}$ and $800 \mathrm{mg} / \mathrm{kg}$ respectively. Thirty minutes later, $0.05 \mathrm{ml}$ of $1 \%$ Carrageenan suspended in sterile $0.9 \%$ 
$\mathrm{NaCl}$ was injected through a $26 \mathrm{G}$ needle into the plantar tissue of the left hind paw of each animal to induce paw edema. Immediately thereafter, the volume of the injected paw was measured using modified plethysmometer. This gives the Initial Paw Volume (IPV). After 3 hours of Carrageenan administration, the paw volume was again measured to get the Final Paw Volume (FPV). The percentage inhibition of paw volume (anti-inflammatory effect) was calculated from the mean values using the formula -Percentage inhibition $=(\mathrm{Vc}-\mathrm{Vt}) / \mathrm{Vc} X 100$, where $\mathrm{Vc}$ was Mean difference in the paw volume of the control and Vt was Mean difference in the paw volume of the test group.

\section{RESULTS}

\section{Acute toxicity studies}

HAEMPWP when administered did not show any sign of toxicity, except for decreased motor activity and muscle relaxation which was evident from 1 hour after administration of the extract. These signs started appearing with a dose of $125 \mathrm{mg} / \mathrm{kg}$ body weight. There was no mortality in any of the test groups even after 24 hours.

\section{Anti-inflammatory activity}

Figure 1 shows the anti-inflammatory activity of mimosa pudica. The mean difference in paw volume which was calculated by subtracting final paw volume (three hours after drug administration) from initial paw volume for each group. Figure 1; indicate that the mean difference in paw volume was less for all doses of the extract and standard drug as compared to control. Analysis using independent sample $\mathrm{t}$ test shows that these values are statistically significant $(\mathrm{p}<0.001)$.

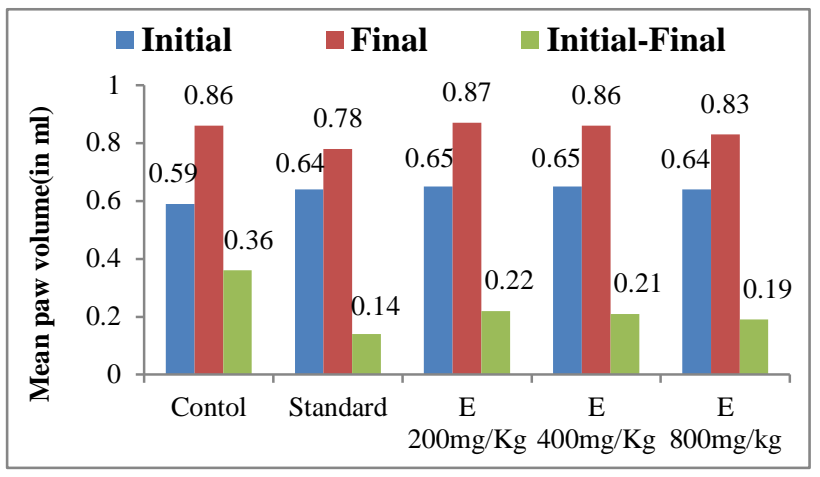

Figure 1: Antiinflammatory activity of HAEMPWP.

The final paw volume as shown in Table 1 was compared using One way ANOVA ( $\mathrm{F}=21.23, \mathrm{p}<0.001)$. Post hoc Dunnett test revealed that there was significant difference in reduction of paw volume as compared to the control. [Standard $\quad(\mathrm{p}<0.001)$, Extract $200 \mathrm{mg} / \mathrm{kg} \quad(\mathrm{p}=0.002)$, Extract $\quad 400 \mathrm{mg} / \mathrm{kg} \quad(\mathrm{p}=0.007), \quad$ Extract $\quad 800 \mathrm{mg} / \mathrm{kg}$ $(\mathrm{p}=0.003)]$.

Table 1: Effect of HAEMPWP on carragenan induced paw edema.

\begin{tabular}{|llllll|}
\multirow{2}{*}{ Treatment } & \multirow{2}{*}{ Dose } & Paw Volume in ml $(\mathbf{n}=\mathbf{6})$ & & \\
\hline Control & & Initial (Mean \pm SEM) & Final (Mean \pm SEM) & Final-Initial (Mean) & \% reduction \\
\hline Standard & & $0.59 \pm 0.01$ & $0.86 \pm 0.01$ & 0.36 & - \\
\hline MP & $200 \mathrm{mg} / \mathrm{kg}$ & $0.65 \pm 0.01$ & $0.78 \pm 0.01^{*}$ & 0.14 & 61.11 \\
\hline MP & $400 \mathrm{mg} / \mathrm{kg}$ & $0.65 \pm 0.01$ & $0.87 \pm 0.01^{*}$ & 0.22 & 38.89 \\
\hline MP & $800 \mathrm{mg} / \mathrm{kg}$ & $0.64 \pm 0.02$ & $0.86 \pm 0.01^{*}$ & 0.21 & 41.66 \\
\hline
\end{tabular}

SEM=Standard Error of Mean* Shows $\mathrm{p}<0.05$ as compared to carrageenan control

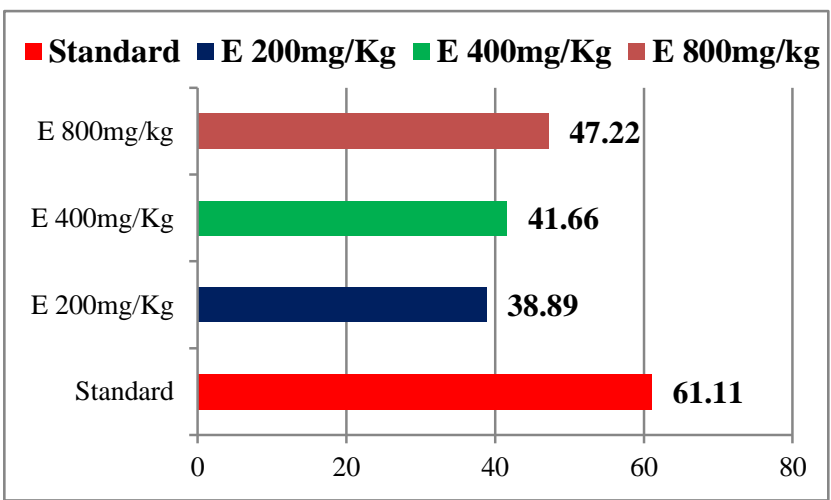

Figure 2: Percentage reduction in paw volume.
Figure 2 shows the percentage inhibition of paw volume of different doses of the extract and aspirin. At 200 $\mathrm{mg} / \mathrm{kg}$, the test drug produced inhibition of paw volume of $38.89 \%$, at a dose of $400 \mathrm{mg} / \mathrm{kg}$ the inhibition of paw volume was $41.66 \%$ and with $800 \mathrm{mg} / \mathrm{kg}$ it was $47.22 \%$. The extract produced a dose dependent increase in the percentage inhibition of paw volume; however it was not statistically significant. The anti-inflammatory effect exhibited by HAEMPWP was not superior to that of standard drug, acetyl salicylic acid, which showed 61.11 percent inhibition of paw volume. 


\section{DISCUSSION}

Our study proves that Mimosa pudica is a very safe drug since it did not produce any mortality when doses up to $3200 \mathrm{mg} / \mathrm{kg}$ were given orally. In a study by Vikram PK et al., the extract showed certain changes in activity and was devoid of any toxicity at dose $2000 \mathrm{mg} / \mathrm{kg}^{22}$

The objective of the present study was to investigate the effect of HAEMPWP on anti-inflammatory activity in Wistar strain albino rats. Carrageenan induced paw edema method is the most prominent experimental model to evaluate acute inflammation. ${ }^{23,24}$ Carrageenan induces biphasic inflammation. The first phase is mediated by release of histamine, serotonin and kinin in the first hour. The second phase is related to the release of prostaglandin like substances in 2-3 hours. ${ }^{25}$ Our study showed a dose dependent increase in inhibition of paw volume with different doses of HAEMPWP, however it was not statistically significant. In the present study HAEMPWP at doses of $200 \mathrm{mg} / \mathrm{kg}, 400 \mathrm{mg} / \mathrm{kg}, 800 \mathrm{mg} / \mathrm{kg}$ produced significant inhibition of Carrageenan induced acute inflammation. Aspirin is a NSAID which produces anti-inflammatory effect by inhibition of prostaglandin synthesis. Further studies have to be carried out to know whether Mimosa pudica extract also act by inhibiting the formation of prostaglandins. Mimosa pudica showed significant effects on acute inflammation. Though the reduction of carrageenan induced paw edema was less when compared to aspirin, the extract produced significant inhibition of paw volume. Majority of the non-steroidal anti-inflammatory drugs produce salt and water retention which is responsible for most of the adverse effects of these very commonly needed drugs. At this point, it is very interesting to note that HAEMPWP has anti-inflammatory effect without causing salt and water retention.

A study done by Mistry et al, showed that leaves of Mimosa pudica possess anti-inflammatory activity. ${ }^{26}$ Results of the study suggests that the extract mainly inhibits the release of prostaglandin like substances. ${ }^{27}$ Mimosa contains flavanoids which possess antiinflammatory activity by inhibiting phospholipase. ${ }^{28}$ Such inhibitors are able to decrease inflammatory response to carrageenan in rats. ${ }^{29}$ Another study done by Goli et al, demonstrated the anti-inflammatory activity of Mimosa pudica leaves. ${ }^{30}$ In a study done by Vikram et.al the ethanolic extract of Mimosa pudica leaves showed $72.31 \%$ inhibition of paw volume at a dose of 500 $\mathrm{mg} / \mathrm{kg}^{22}$

Mimosa pudica is found to be highly effective in relieving the symptoms of rheumatoid arthritis and muscular pain. It is used for treating spasmodic conditions and fever. Many studies have substantiated the antibacterial, anti-inflammatory, analgesic and other effects of the plant. Studies done on Mimosa pudica justify the therapeutic application of this plant in indigenous system of medicine augmenting its therapeutic value.

The major limitation of the study is that the effect of the extract on chronic inflammation was not studied and phytochemical analysis was not done to identify the exact constituents. Further extensive phytochemical analysis and research is necessary to identify the exact constituents and understanding of the possible mechanism of action of anti-inflammatory activity of HAEMPWP.

\section{CONCLUSION}

The present study showed that the extract of Mimosa pudica is safe and possessed anti-inflammatory activity in experimental models. This rationalizes its use as an antiinflammatory agent in traditional systems of medicine. Toxicity studies confirm the safety of the drug. The results of this study emphasise the need for further investigation of active principles. The plant possesses many other properties which is evident from its use in folklore which needs further evaluations. These studies will help to support the use of this plant for human and animal diseases.

\section{Funding: No funding sources}

Conflict of interest: None declared

Ethical approval: The study was approved by the Institutional Ethics Committee

\section{REFERENCES}

1. Katzung BG. Basic and clinical Pharmacology. 10th ed. New York: Mc Graw Hill; 2007:314.

2. Mitchell RN, Cotran RS. In: Kumar V, Cotran RS, Robbins SL. (Eds). Basic Pathology. 6th ed. Bangalore: Prism Books Pvt Ltd; 1997:25-46.

3. Rang HP, Dale MM, Ritter JM, Flower RJ. Pharmacolgy. $6^{\text {th }}$ ed. Elseiver: Churchill Livingstone; 2007:218-20.

4. Satoskar RS, Rege NN, Bhandarkar SD. Pharmacology and Pharmacotherapeutics. $24^{\text {th }}$ ed. Mumbai: Popular Prakasan; 2015:168.

5. Winter CA, Risley EA, Nuss GW. Carrageenan induced edema in hind paw of the rat as an aasay for anti-inflammatory drugs. Proc Soc Exp Biol Med. 1962;3:544-7.

6. Nadkarni KM. Indian Materia Medica. 3rd ed. Vol 1. Bombay: Popular Prakashan pvt Ltd; 1976:799-800.

7. Howard RA. Flora of the Lesser Antilles, Leewards and Windward Islands in Dicotyledonea, Part 1, Jamaica Plain MA: Arnold Arboretum, Harvard University; 1988;4:673.

8. Satyavati G, Gupta AK, Tandon N. Medicinal plants of India.3rd ed.Vol 2. Bombay: Popular Prakashan pvt Ltd; 1987:254-6.

9. Kirtikar KR, Basu BD. Indian medicinal plants. 2nd ed. Vol 2. Dehradun: Bishen Singh Mahendrapal Singh; 1935:915-17. 
10. Warrier PK, Nambiar VPK, Ramankutty C. Indian Medicinal Plants, a compendium of 500 species. 1st ed. Vol5. Madras: Orient Longman Ltd; 1997:263.

11. Tamilarasi T, Ananthi T. Phytochemical analysis and antimicrobial activity of Mimosa pudica Linn. Res J Chem Sci. 2012;2:72-4.

12. Hafsa A, Sakshi S, Anurag M, Rajiv G. Mimosa pudica L. (Laajvanthi): An overview. Pharmacogn Rev. 2012;6:115-24.

13. Sengupta KNN. The Ayurvedic system of Medicine. 2nd ed. Vol1. New Delhi: Sri Satguru Publications; 1987:374-5.

14. Tirtha SSS. The Ayurvedic Encyclopedia: Natural secrets for healing, prevention and longevity. $1^{\text {st }}$ ed. New Delhi: Sri Satguru Publications; 1976:214.

15. Chopra RN, Nayar SL, Chopra IC. Glossary of Indian medicinal plants. New Delhi: CSIR; 1988:167.

16. Bahekar PC, Shaikh HY, Nigade PB, Ghaisas MM. Antihistaminic activity of aqueous extract of Mimosa pudica Linn. J Pharm Research. 2007;63:134-8.

17. Nair PV, Nair B. Muscle relaxant activity of hydroalcoholic extract of Mimosa pudica whole plant in mice. Natl J Physiol Pharm Pharmacol. 2017;7.

18. Vejayan J, Ibrahim H, Othman I. The potential of Mimosa pudica against snake envenomation. J Trop Forest Sci. 2007;19:189-97.

19. Rosenthaler L. The chemical investigations of plants. London: G Bell and sons Ltd; 1930:67.

20. Ghosh MN. Fundamentals of experimental Pharmacology. 2nd ed. Calcutta: Hilton and Company. 2005:190-4.

21. Singh H, Ghosh MN. Modified plethysmometer for measuring foot volume of unanaesthetised rats. J Pharm Pharmacol. 1968;20:316-7.

22. Vikram PK, Malavi R, Jain DK. Evaluation of analgesic and anti-inflammatory potential of Mimosa pudica Linn. Int J Curr Pharm Res. 2012;4:47-50.
23. Vogel HG, Vogel WH. Drug Discovery and Evaluation: Pharmacological assays. 2nded. New York: Springer - Verlag Berlin Heidelberg. 2002:759-61.

24. Garaa MD, Fernandez MA, Alvaraz A, Saenz MT. Antinociceptive and anti-inflammatory effect of the aqueous extract from leaves of Pimenta racemosa var ozua (Myrtaceae). J Ethn Pharm. 2004;91:69-73.

25. Brooks PM, Day RO. Nonsteroidal antiinflammatory drugs- differences and similarities. N Engl J Med. 1991;324:1716-25.

26. Mistry S, Patidar R, Vyas V, Jena J, Dutt KR. Antiinflammatory activity of Mimosa pudica Linn (Mimosaceae) leaves: An ethnopharmacological study. J Pharm Sci Res. 2012;4:1789-91.

27. Fowzy AA, Vishwanath BS, Frason RC. Inhibition of human non-pancreatic phospholipase $\mathrm{A} 2$ by retinoids and flavonoids. Mechanism of Action. Agents Action. 1988;25:394.

28. Ferrandiz ML, Alcaraz MJ. Anti-inflammatory activity and inhibition of arachidonic acid metabolism by flavonoids. Agents Action. 1991;32:283-8.

29. Aitchdrfoun M, Mounnier C, Heymons F, Bon C, Binistic C, Godfroid JJ. 4-Alkoxybenzamidines as new potent phospholipase A2 inhibitors. Biochem Pharmacol. 1996;51:737.

30. Goli V, Bhaskar KV, Macharla SP, Bhaskar J, Devi PS, Ramchander T. Effects of anti-inflammatory activity of Mimosa pudica. Asian J Pharm Res. 2011;1:69-71.

Cite this article as: Nair PV, Nair BLR. Antiinflammatory activity of hydroalcoholic extract of mimosa pudica whole plant in rats. Int $\mathbf{J}$ Basic Clin Pharmacol 2017;6:518-22. 